\title{
Assessment of intake of iron and nutrients that affect bioavailability of daily food rations of girls
}

\author{
Anna Broniecka', Joanna Wyka', Monika Bronkowska', Ewa Piotrowska', Jadwiga Biernat ${ }^{1}$ \\ ${ }^{1}$ Department of Human Nutrition, University of the Environmental and Life Sciences, Wrocław, Poland
}

Broniecka A, Wyka J, Bronkowska M, Piotrowska E, Biernat J. Assesment of the intake of iron and nutrients that affect its bioavailability from daily food rations of girls. Ann Agric Environ Med. 2014; 21(2): 327-330. doi: 10.5604/1232-1966.1108598

\begin{abstract}
Introduction. In the human body iron occurs at a level of $3-5 \mathrm{~g}, 60-70 \%$ of which are in haemoglobin, ca. $10 \%$ in myoglobin, and ca. $3 \%$ are accumulated in enzymes of cellular respiration or enzymes degrading toxic hydrogen peroxide. The other part of iron is accumulated in the liver, spleen, kidneys and bone marrow. The dietary deficiency of iron appears at its insufficient level in a diet and at impaired absorption of iron ions present in food products by a body. Groups at an especially high risk of iron deficiencies include, among others, menstruating girls in the pubescence period and women with heavy and irregular menstruations, as well as vegetarians and patients with chronic enteritis.

Objective. To evaluate the intake of iron and nutrients that affect its bioavailability from daily food rations of girls.

Materials and method. The study comprised 159 girls aged 17-18, students of high schools in the city of Wroclaw, southwestern Poland. The study was conducted between November 2010 - May 2011. The girls were divided into 3 subgroups according to the BMI score. Their ' diets were analyzed by the method of a direct interview 24 hours before the test. The interview was repeated seven times.

Results. The presented study demonstrates that the intake of iron from food rations of almost all the girls surveyed was below the requirements defined for this age group. Statistically significant differences were noted in the intake of energy and nutrients among the three distinguished subgroups of girls.

Conclusions. Food rations of the surveyed girls were characterized by a low energetic value, compared to dietary allowances, which resulted in deficiencies of nutrients increasing iron bioavailability.
\end{abstract}

\section{Key words}

iron, girls, iron intake, iron bioavailability

\section{INTRODUCTION}

In the human body iron occurs at a level of 3-5 g, 60-70\% of which are in haemoglobin, ca. $10 \%$ in myoglobin, and ca. 3\% accumulated in enzymes of cellular respiration or enzymes degrading toxic hydrogen peroxide. The other part of iron is accumulated in the liver, spleen, kidneys and bone marrow [1]. Owing to the presence in cellular structures, iron serves many important functions, the key ones include oxygen transportation, red and white blood cells generation or formation of myelin in the developing brain of small children [2].

In the body, iron is transported as transferrin and accumulated in the form of ferritin and haemosiderin. Its concentration in blood is controlled by appropriate absorption from food, transportation in the body, accumulation and physiological loss - the latter including iron excreted with urine, exfoliated epidermis and faeces [3]. Iron absorption is an active process, the effectiveness of which reaches ca. 3-6\%, proceeds mainly in the duodenum and jejunum, and includes both ferrous $\left(\mathrm{Fe}^{2+}\right)$ and ferric $\left(\mathrm{Fe}^{3+}\right)$ ions. The absorption of the heme form ranges from 5-35\%, whereas that of the nonheme form from 2-20\%. Iron bioavailability from a mixed food ration fluctuates between $15-18 \%[4,5]$. In the case of heme - it penetrates as a whole to enterocytes and releases

Address for correspondence: Anna Broniecka, Department of Human Nutrition, University of the Environmental and Life Sciences, Chełmońskiego 37/41, 51-630 Wroclaw, Poland

e-mail: anna.broniecka@up.wroc.pl

Received: 27 September 2012; accepted: 22 March 2013 the ferrous ions which are absorbed from intestinal digesta more readily than the ferric ions. The process of iron ions absorption from a food ration is enhanced by ascorbic acid, resistant starch, oligosaccharides vitamin $A$ and $\beta$-carotene, whereas it is impaired by dietary fibre, phytic acid, calcium, manganese, zinc, copper, phosphates, oxalates, and alcohol $[5,6]$. Fibre does not adversely affect the absorption of iron. Products rich in iron also contain phytic acid compounds. In the small intestine there are formed insoluble complexes between non-heme iron and protein degradation products and phytic acid compounds [2].

The dietary deficiency of iron appears at its insufficient level in a diet and at impaired absorption of iron ions present in food products by a body. Bioavailability of this element is especially low in persons whose diet is based mainly on plant-originated foods [7]. Groups at an especially high risk of iron deficiencies include, among others, menstruating girls in the pubescence period and women with heavy and irregular menstruations, as well as vegetarians and patients with chronic enteritis [1]. Iron deficiency in the body and the resultant anaemia are claimed to be one of the determinants of the poor health status of ca. 2 billions persons worldwide [7]. The global estimates of the WHO show that $19 \%$ of children under 5 years of age, $24 \%$ of children at the age of $5-14,21 \%$ of women and ca. $26 \%$ of pregnant women suffer from anaemia due to iron deficiency [8]. In Poland, anaemia due to iron deficiency has been diagnosed in $10 \%$ of women between the ages of 15-44 [9]. A consequence of this disease is also an increased risk of immunological disorders, susceptibility to infections, risk of spontaneous or pre-mature delivery, and perinatal complications [10]. 
The objective of this study was to evaluate the intake of iron and nutrients affecting its bioavailability from daily food rations of girls at the age of 17-18 from Wrocław and neighboring areas in south-west Poland.

\section{MATERIAL AND METHODS}

The study covered a group of 159 girls at the age of 17-18, attending secondary, technical and occupational schools in Wrocław. The criterion of school selection for the study was affiliation to a network of schools promoting health. The study was carried out between November 2010 - May 2011. The intake of iron from daily food rations (DFR) and of nutrients affecting its availability was assessed by the method of a direct interview of the last 24 hours, and repeated 7 times. The food portion size was estimated by means of the Album of Photographs of Food Products and Dishes (IŻŻ, 2000). Daily food rations were introduced into computer programme ENERGY v4.1, which interacts with the database created by Kunachowicz et al. in Table of Composition and Nutritional Value of Food (2005). Results were compared with Estimated Average Requirements (EAR) appropriate for gender and age [11]. The nutritional status of the body was evaluated based on, among others, anthropometric measurements that included measurements of body height and body mass, using a medical scale with a height meter, exact to $0.1 \mathrm{~cm}$ (body height) and $0.1 \mathrm{~kg}$ (body mass). Afterwards, the BMI values were computed and the nutritional status of the adolescent girls interpreted according to centile charts for respective age category and gender [12].

Results obtained were subjected to statistical analysis using STATISTICA 10.0 software. Results were evaluated by the non-parametric Kruskal-Wallis test for comparisons between three groups, because data obtained were not characterized by normal distribution. Results were presented using median and quartile deviation (Tab. 1).

\section{RESULTS AND DISCUSSION}

In the survey, the girls were divided into three subgroups, depending on the BMI value correlated with centile charts for respective gender and age category. The boundary values of the nutritional status were adopted as follows::

- subgroup $1(\mathrm{n}=22): \leq 5$. percentile, i.e. $\mathrm{BMI} \leq 17.5 \mathrm{~kg} / \mathrm{m}^{2}$

- subgroup $2(\mathrm{n}=103)$ : between $5-85$. percentile, i.e. BMI between $17.6 \mathrm{~kg} / \mathrm{m}^{2-} 24 \mathrm{~kg} / \mathrm{m}^{2}$

- $\operatorname{subgroup} 3(\mathrm{n}=34): \geq 85$. percentile, i.e $\mathrm{BMI} \geq 24 \mathrm{~kg} / \mathrm{m}^{2}$

Mean BMI values in particular subgroups accounted for $16.9 \mathrm{~kg} / \mathrm{m}^{2}, 21.2 \mathrm{~kg} / \mathrm{m}^{2}$, and $28.4 \mathrm{~kg} / \mathrm{m}^{2}$, respectively. Table 1 presents median of the energetic value of daily food rations (DFR) and median of the intake of selected nutrients, vitamins and minerals by the surveyed girls, in particular subgroups.

The median of the energetic value of DFR in the whole surveyed group reached 1,385.0 $\pm 619.8 \mathrm{kcal} /$ day, and differed statistically significantly between particular subgroups (Tab. 1). The daily food rations of the investigated girls were covering $63 \%$ of the EAR for energy $(2,200 \mathrm{kcal} / \mathrm{day})$. The energetic value of DFR of underweight girls was higher than that of the girls with normal body mass value, and that of the girls with overweight/obesity.
Results obtained in the presented survey were lower than in a study by Piotrowska et al. [13] that covered 409 girls aged 16-18 from Wrocław. The mean energetic value reached $1,942.1 \pm 815.9 \mathrm{kcal} /$ days, the same as in a survey by Trafalska and Grzybowski with 198 girls aged 20-26 from Łódź, whereas the median of the energetic value of DFR accounted for $1,992.3 \pm 259.6 \mathrm{kcal} /$ day [14]. Investigations conducted by Larson et al. [15] among 946 American girls aged 18-24 showed that the mean energetic value of their food rations reached 1,682 kcal/day. A Canadian study by Deegan et al. [16], conducted among 241 healthy girls aged 13-19, with BMI values of $21.7 \pm 3.7 \mathrm{~kg} / \mathrm{m}^{2}$, showed that the energetic value of their food rations accounted for 2,915 kcal/day, whereas lower results were achieved by Hoppe et al. [17] who analyzed 15-16-year-old Swedish girls. In the case of 28 Swedish female adolescents with BMI of $20.6 \mathrm{~kg} / \mathrm{m}^{2}$, the mean energetic value of DFR reached 2,125.7 $\pm 358.3 \mathrm{kcal} /$ day [17].

In the food ration of the surveyed girls in the presented study, the median of iron content accounted for $6.4 \pm 2.8 \mathrm{mg} / \mathrm{day}$ (Tab. 1), and was below the EAR value, i.e. $8 \mathrm{mg} /$ day [11]. Statistically significant differences occurred between the subgroups (Tab. 1). The lowest intake of iron was observed in subgroup 3, whereas the highest (6.7 $\mathrm{mg}$ /day) in subgroup 1 . Additionally, among $25 \%$ of the girls from the latter group the intake of iron exceeded $9.7 \mathrm{mg} /$ day (Q3). Those results, however, were lower than the findings of Wolnicka and Taraszewska [18] who surveyed 193 girls aged 11-13 from Warsaw, and demonstrated that iron content in their food rations reached 7.4 $\pm 3.1 \mathrm{mg} /$ day. Szczepańska et al. [19], who investigated the nutritional patterns of 16-18-year-old rural and urban girls from the Silesia Province, demonstrated a mean iron intake at a level of $7.2 \pm 1.7 \mathrm{mg} /$ day in both urban and rural girls. In research by Piotrowska et al. [20], the iron level in the girls' diet was shown to reach $10.3 \pm 5.9 \mathrm{mg} /$ day. This was the same as in a study by Trafalska and Grzybowski [14], where the median of iron content in a diet accounted for $11.9 \pm 2.2 \mathrm{mg} /$ day in underweight girls, and for $8.6 \pm 2.2 \mathrm{mg} /$ day in girls with correct body mass. Adolescent girls surveyed by Tussing-Humpherys et al. [21] were also divided into subgroups based on their body mass values. Out of the 210 American girls aged 12-17 years, 129 were characterized by a proper body mass, whereas 81 were overweight. The intake of iron in these groups reached $13.4 \mathrm{mg} /$ day and $12.1 \mathrm{mg} /$ day, respectively. In turn, Hoppe et al. [17] demonstrated that iron intake from DFR of the investigated Swedish girls was at a level of $11.5 \pm 2.8 \mathrm{mg} /$ day. Similar results were obtained by Larson et al. [15] where the iron content in a daily food ration accounted for $13.4 \mathrm{mg} /$ day, whereas in DFR of girls surveyed by Deegan et al. [16] - 20.5 $\pm 9.4 \mathrm{mg} /$ day.

Of the nutrients affecting increased iron bioavailability, of special significance is vitamin $\mathrm{C}$. The mechanism of the positive effect of vitamin $\mathrm{C}$ on the absorption is explained by its ability to reduce ferric ions to ferrous ions in the small intestine, and chelating capacity to create soluble complexes of iron [2]. In the surveyed girls in the presented study, the median of vitamin C intake reached $23.2 \pm 20.1 \mathrm{mg} /$ day, which was lower than the recommended value, i.e. $55 \mathrm{mg} /$ day [11]. Those results were similar to findings of Szczepańska et al. [19] who demonstrated that the mean intake of vitamin C from food rations of girls surveyed in their study reached $38 \pm 17 \mathrm{mg} /$ day. In the case of girls investigated by Wolnicka and Taraszewska [18], vitamin $\mathrm{C}$ intake accounted for $74.3 \pm 87.9 \mathrm{mg} /$ day, similar to adolescent girls investigated 


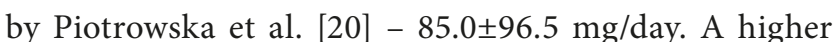
content of ascorbic acid was noted in daily food rations of the underweight girls investigated by Trafalska and Grzybowski [14] - $125.2 \mathrm{mg} / \mathrm{day}$, and in those with excessive body mass surveyed by Tussing-Humpherys et al. [21] - $89.5 \mathrm{mg} /$ day. In turn, vitamin C content in diets analyzed by Larson et al. [15] accounted for $119.5 \mathrm{mg} /$ day.

In the presented study, the intake of vitamin A and betacarotene, other nutrients that enhance iron absorption, from DFR reached $467.6 \pm 82.2 \mu \mathrm{g} /$ day and $1512.5 \pm 1772.2 \mu \mathrm{g} /$ day, respectively. The intake of vitamin A was below the EAR value $(490 \mu \mathrm{g} /$ day $)$. No statistically significant differences were demonstrated between the subgroups (Tab. 1); however the results obtained were lower than those reported by Trafalska and Grzybowski [14]. The intake of vitamin A and beta-carotene among girls with deficient and proper BMI accounted for, respectively: $1112.4 \pm 625.8 \mu \mathrm{g}$ and $3328.1 \pm 3526.6 \mu \mathrm{g}$ vs. $696.2 \pm 508.5 \mu \mathrm{g}$ and $2168.9 \pm 2652.1 \mu \mathrm{g}$ [14]. In other studies cited in this work, the intake of vitamin A reached $810.7 \pm 638.1 \mu \mathrm{g}$ in the case of adolescent girls from Wrocław [20], 771.2 $\pm 596.9 \mu \mathrm{g}$ in the case of girls from Warsaw [18], and $909.8 \mu \mathrm{g}$ in the case of young American girls [15].

The content of total protein as a dietary component increasing iron bioavailability in the food rations of the surveyed girls reached $48.6 \pm 19.4 \mathrm{~g} /$ day. Statistically significant differences were observed between the subgroups (Tab. 1). The lowest intake of total protein was noted in the girls with excessive body mass - $43.1 \mathrm{~g} /$ days, whereas the highest in the subgroup with deficient body mass $-58.3 \mathrm{~g} /$ day. The median of plant and animal protein intake from food rations of adolescent girls from Wrocław accounted for, respectively, $16.9 \pm 6.8 \mathrm{~g} /$ day and $29.5 \pm 14.4 \mathrm{~g} / \mathrm{day}$. The subgroups were found to differ statistically significantly in this respect (Tab. 1). The highest intake of both plant and animal protein was determined in the case of girls from subgroup 1, whereas the lowest in the subgroup of girls with excessive body mass. In research by Piotrowska et al. [13], the content of total protein in food rations was higher and reached $59.7 \pm 25.3 \mathrm{~g} / \mathrm{day}$, whereas the contents of plant and animal protein were equalized and reached $25.2 \pm 11.9 \mathrm{~g} /$ day and $34.5 \pm 16.8 \mathrm{~g} /$ day, respectively. Higher values were also achieved by Trafalska and Grzybowski [14]. The intake of total protein and those of plant and animal protein by female adolescents surveyed in their study, accounted for, respectively: 70.8 $\pm 13.2 \mathrm{~g} /$ day, $27.9 \pm 5.4 \mathrm{~g} /$ day and $36.6 \pm 11.9 \mathrm{~g} /$ day.

Of the nutrients that affect a reduction in iron bioavailability in the body, those most frequently enumerated include: calcium, zinc, copper, manganese and dietary fibre. The intake of calcium from daily food rations of the surveyed girls reached $447.0 \pm 257.5 \mathrm{mg} /$ day and did not differ statistically significantly between the subgroups (Tab. 1). However, it was lower than the AI value reaching 1,300 mg/day. A higher calcium intake than in the presented study was reported by Piotrowska et al. [20] - 596.2 mg, Wolnicka and Taraszewska [18] - 617.3 mg, Trafalska and Grzybowski [14] - 656 mg, on average, and by Larson et al. [15] - $831.8 \mathrm{mg}$. In contrast, a lower content of calcium in DFR was noted in the study by Szczepańska et al. [19] - 486 mg.

In the presented study, the intake of other minerals affecting the lower bioavailability of iron, i.e. zinc, copper and manganese, was below recommended values and reached, respectively: $5.8 \pm 2.7 \mathrm{mg}, 0.6 \pm 0.3 \mathrm{mg}$, and $2.4 \pm 1.3 \mathrm{mg}$. Statistically significant differences were observed between the subgroups in zinc and copper intake, whereas there were no differences in the intake of manganese (Tab. 1). The highest intake of these elements was noted in subgroup 1 , whereas the lowest in subgroup 3. Contents of copper and zinc in food rations in the above-cited studies were also below recommended values and reached 7.0-8.6 $\mathrm{mg}$ for zinc $[14,18,20]$ and $0.7-1.1 \mathrm{mg}$ for copper $[14,18,20]$. The intake of dietary fibre from a daily food ration, both in the presented study and in surveys conducted by Piotrowska et al. [13], Trafalska and Grzybowski [14], and Larson et al. [15], was below the recommended value ( $>25 \mathrm{~g} /$ day) and accounted for $10.4 \mathrm{~g}, 13.9 \mathrm{~g}, 16.9 \mathrm{~g}$, and $20.3 \mathrm{~g}$, respectively.

Table 1. Energetic value of daily food rations and intake of selected nutrients, vitamins and minerals by the surveyed girls ( $\mathrm{n}=159$ )

\begin{tabular}{|c|c|c|c|c|c|c|c|c|c|c|c|c|}
\hline \multirow{2}{*}{ ENERGY AND NUTRIENTS } & \multicolumn{2}{|c|}{ TOTAL $n=159$} & \multicolumn{4}{|c|}{ SUBGROUP $1 \quad n=22$} & \multicolumn{3}{|c|}{ SUBGROUP $2 n=103$} & \multicolumn{3}{|c|}{ SUBGROUP $3 n=34$} \\
\hline & $M e \pm Q D$ & $Q_{1}$ & $\mathbf{Q}_{3}$ & $M e \pm Q D$ & $\mathbf{Q}_{1}$ & $\mathbf{Q}_{3}$ & $M e \pm Q D$ & $Q_{1}$ & $\mathbf{Q}_{3}$ & $M e \pm Q D$ & $Q_{1}$ & $\mathbf{Q}_{3}$ \\
\hline Energy [kcal] & $1385.0 \pm 619.8$ & 1108.1 & 1727.9 & $1588.7 \pm 638.6^{a}$ & 1366.2 & 2004.9 & $1395.5 \pm 573.3^{b}$ & 1144.2 & 1717.5 & $1138.8 \pm 778.1^{a . b}$ & 846.0 & 1624.1 \\
\hline Total protein [g] & $48.6 \pm 19.4$ & 37.1 & 56.5 & $58.3 \pm 23.7^{a}$ & 43.0 & 66.7 & $49.1 \pm 19.0$ & 37.5 & 56.5 & $43.1 \pm 14.4^{\mathrm{a}}$ & 34.6 & 49.0 \\
\hline Animal protein [g] & $29.5 \pm 14.4$ & 22.2 & 36.6 & $37.6 \pm 17.6^{\mathrm{a}}$ & 26.2 & 43.9 & $29.4 \pm 13.9$ & 22.2 & 36.2 & $27.0 \pm 10.9^{a}$ & 19.8 & 30.7 \\
\hline Plant protein [g] & $16.9 \pm 6.8$ & 14.0 & 20.8 & $19.8 \pm 9.1^{\mathrm{a}}$ & 15.0 & 24.2 & $16.9 \pm 7.1^{\mathrm{b}}$ & 14.4 & 21.5 & $15.6 \pm 7.1^{a . b}$ & 10.6 & 17.7 \\
\hline Total carbohydrates [g] & $183.6 \pm 82.9$ & 148.5 & 231.4 & $204.1 \pm 92.2^{\mathrm{a}}$ & 173.8 & 266.0 & $187.5 \pm 81.7^{\mathrm{b}}$ & 152.7 & 234.5 & $150.0 \pm 80.2^{a . b}$ & 119.9 & 200.1 \\
\hline Calcium [mg] & $447.0 \pm 257.5$ & 218.0 & 575.5 & $538.8 \pm 347.4$ & 350.9 & 698.2 & $463.0 \pm 254.3$ & 332.4 & 586.7 & $383.7 \pm 202.0$ & 294.0 & 496.0 \\
\hline Iron [mg] & $6.4 \pm 2.8$ & 5.0 & 7.8 & $6.7 \pm 4.0^{\mathrm{a}}$ & 5.7 & 9.7 & $6.5 \pm 3.1$ & 5.0 & 8.1 & $5.6 \pm 2.4^{a}$ & 4.6 & 7.1 \\
\hline Zinc [mg] & $5.8 \pm 2.7$ & 1.5 & 7.1 & $7.1 \pm 2.7^{\mathrm{a}}$ & 5.6 & 8.4 & $5.8 \pm 2.6$ & 4.5 & 7.1 & $4.7 \pm 1.6^{a}$ & 4.4 & 6.0 \\
\hline Copper [mg] & $0.6 \pm 0.3$ & 0.5 & 0.8 & $0.7 \pm 0.3^{\mathrm{a}}$ & 0.6 & 0.9 & $0.6 \pm 0.3^{b}$ & 0.5 & 0.8 & $0.6 \pm 0.2^{\mathrm{a} . \mathrm{b}}$ & 0.4 & 0.6 \\
\hline Vitamin A [ $\mu \mathrm{g}]$ & $467.6 \pm 382.2$ & 307.5 & 689.7 & $515.8 \pm 426.4$ & 396.9 & 823.3 & $483.6 \pm 411.2$ & 302.4 & 713.6 & $438.2 \pm 327.8$ & 285.5 & 613.3 \\
\hline Beta-carotene $[\mu \mathrm{g}]$ & $1512.5 \pm 1772.2$ & 750.8 & 2523.0 & $2254.5 \pm 2354.9$ & 782.6 & 3137.4 & $1518.0 \pm 1642.6$ & 750.8 & 2393.4 & $1417.2 \pm 1362.3$ & 701.3 & 2063.6 \\
\hline Vitamin C [mg] & $23.2 \pm 20.1$ & 15.6 & 36.6 & $23.1 \pm 12.0$ & 18.1 & 30.1 & $27.2 \pm 28.9$ & 15.5 & 44.4 & $20.0 \pm 12.3$ & 15.6 & 27.9 \\
\hline Dietary fiber [g] & $10.4 \pm 5.9$ & 8.2 & 14.1 & $11.8 \pm 7.4^{\mathrm{a}}$ & 9.5 & 16.9 & $10.4 \pm 6.3$ & 8.2 & 14.5 & $9.2 \pm 4.2^{\mathrm{a}}$ & 7.5 & 11.7 \\
\hline
\end{tabular}

a - statistically significant differences between subgroups 1 and 3

- statistically significant differences between subgroups 2 and 3 


\section{CONCLUSIONS}

1. Food rations of the surveyed girls were characterized by a low energetic value, compared to dietary allowances, which resulted in deficiencies of nutrients increasing iron bioavailability.

2. Iron intake from daily food rations of each of the surveyed subgroups did not cover the daily demand for this mineral component.

3. The daily food rations of the underweight girls were meeting dietary allowances and recommendations for energy and nutrients to the greatest extent.

\section{REFERENCES}

1. Huch R, Schaefer R. Niedobór żelaza i niedokrwistość z niedoboru żelaza. Wyd. MedPharm Polska, Wrocław, 2008 (in Polish).

2. Grajeta H. Wpływ składników pokarmowych na wchłanianie żelaza. Bromat. Chem. Toksykol., 2006; 39(2): 111-119 (in Polish).

3. Jamison JR. Clinical guide to nutrition \& dietary supplements in disease management. Wyd. Churchill Livingstone, Victoria, Australia, 2006.

4. Gronowska-Senger A. Zarys oceny żywienia. Wyd. SGGW, Warszawa, 2009 (in Polish)

5. Keller JS. Podstawy fizjologii żywienia człowieka. Wyd. SGGW, Warszawa, 2000 (in Polish).

6. Gröber U. Mikroskładniki odżywcze. Tuning metaboliczny - profilaktyka - leczenie. Wyd. MedPharm Polska, Wrocław, 2010 (in Polish).

7. Zimmermann MB, Hurrell RF. Nutritional iron deficiency. Lancet, 2007; 370: 511-520.

8. WHO/UNICEF/UNU. Iron deficiency anemia assessment, prevention and control. Geneva, WHO, 2001.

9. Ezzati M, Lopez AD, Rodgers A, Murray CJL (eds.). Comparative quantification of health risks: global and regional burden of disease attributable to selected major risk factors. Geneva, WHO, 2004

10. Wądołowska L. Żywieniowe podłoże zagrożeń zdrowia w Polsce. Wyd. UWM, Olsztyn, 2010 (in Polish).
11. Jarosz M, Bułhak-Jachymczyk B. Normy żywienia człowieka. Podstawy prewencji otyłości i chorób niezakaźnych. Wyd. PZWL, Warszawa, 2008 (in Polish).

12. Kułaga Z, Różdżyńska A, Palczewska I, Grajda A, Gurzkowska B, Napieralska E, Litwin M oraz Grupa Badacza OLAF: Siatki centylowe wysokości, masy ciała i wskaźnika masy ciała dzieci i młodzieży w Polsce - wyniki badania OLAF. Stand. Med. 2010; 7: 690-700 (in Polish).

13. Piotrowska E, Mikołajczak J, Biernat J, Żechałko-Czajkowska A. Ocena sposobu żywienia dziewcząt 16-18-letnich z Wrocławia i okolic w aspekcie zagrożenia chorobami żywieniowozależnymi. Cz. I. Składniki podstawowe. Bromat. Chem. Toksykol. 2012; 45(1): 39-48 (in Polish).

14. Trafalska E, Grzybowski A. Charakterystyka sposobu żywienia młodych kobiet z niedoborem masy ciała. Now. Lek. 2006; 75(6): 538-542 (in Polish)

15. Larson NI, Neumark-Sztainer D, Hannan PJ, Story M. Family meals during adolescence are associated with higher diet quality and healthful meal patterns during young adulthood. J Am Diet Assoc. 2007; 107: 1502-1510.

16. Deegan H, Bates HM, McCargar LJ. Assessment of iron status in adolescents: dietary, biochemical and lifestyle determinants. J Adolescent Health. 2005; 37(75): 15-21.

17. Hoppe M, Sjöberg A, Hallberg L, Hulthén L. Iron status in Swedish teenage girls: impact of low dietary iron bioavailability. Nutrition 2008; 24 : 638-645.

18. Wolnicka K, Taraszewska A. Ocena zawartości witamin i składników mineralnych w całodziennej racji pokarmowej uczniów V i VI klas wybranych warszawskich szkół podstawowych. Probl Hig Epidemiol. 2012; 93(2): 408-413 (in Polish).

19. Szczepańska E, Bielaszka A, Mikoda M, Kiciak A. Ocena zawartości wapnia i żelaza w jadłospisach licealistek zamieszkałych na wsi i w mieście na terenie województwa śląskiego. Hyg Pub Health. 2011; 46(2): 266-272 (in Polish).

20. Piotrowska E, Mikołajczak J, Biernat J, Żechałko-Czajkowska A. Ocena sposobu żywienia dziewcząt 16-18-letnich z Wrocławia i okolic w aspekcie zagrożenia chorobami żywieniowozależnymi. Cz. II. Witaminy i składniki mineralne. Bromat. Chem. Toksykol., 2012; 45(1): 49-58 (in Polish)

21. Tussing-Humpherys LM, Liang H, Nemeth E, Freels S, Braunschweig CA. Excess adiposity, inflammation and iron-deficiency in female adolescents. J Am Diet Assoc. 2009; 109: 297-302. 